International Journal of Agriculture, Environment and Bioresearch

Vol. 6, No. 01; 2021

ISSN: $2456-8643$

\title{
SOLID HOUSEHOLD WASTE MANAGEMENT IN COTONOU: STATE OF PLAY AND PROSPECTS
}

\author{
Bienvenu S. AGBANI ${ }^{1}$, Roméo KADJEGBIN ${ }^{2}$, Follygan ETCHELI ${ }^{3}$ and Léon Bani BIOBIGOU ${ }^{4}$ \\ ${ }^{1}$ DépartementdeGéographieetAménagementduTerritoire,Universitéd'Abomey-Calavi,01BP526Cotonou(Bénin), Tél: \\ 97922525Laboratoired'EtudedesDynamiquesUrbaineset Régionales \\ ${ }^{2}$ Maître-Assistant à l'Université d'Abomey-Calavi, Laboratoire d'Etudes des Dynamiques Urbaines et Régionales \\ (LEDUR), BP : 381 GodomeyTél : (00229) 96089777 \\ ${ }^{3}$ Professeur Titulaire à la Faculté des Sciences de l'Homme et de la Société de 1'Université de Lomé, Tél : (+228) \\ 90192708 \\ ${ }^{4}$ Professeur Titulaire à l'Université d'Abomey-Calavi, Laboratoire d'Etudes des Dynamiques Urbaines et \\ Régionales (LEDUR), Tél : (+229) 97575784BP : 217 Abomey-Calavi/ Bénin
}

https://doi.org/10.35410/IJAEB.2021.5599

\begin{abstract}
The management of solid household waste is a big problem in the city of Cotonou. This study aims to take stock of the management of solid household waste in Cotonou after three terms of decentralization practice. The methodological approach is based on documentary research, field surveys, data processing. The field survey involved 2 officials of COGEDA, $50 \%$ of heads of SMEs, 4 officials of the DST (Town Hall / Cotonou) and 5 officials of the waste management and sanitation company in "Grand Nokoué". The application of this methodology produced the following results:

Taking into account decentralized urban management mechanisms, from 2001 to 2019, the option chosen by municipal authorities in terms of solid waste management is to "do-do" with obligation of results. It is based on two basic principles, which are participatory and shared management. The amount of waste produced per day in Cotonou is $1000 \mathrm{~kg}$, and the removal rate is $500 \mathrm{~kg}$. Indeed, $85 \%$ of the waste produced in Cotonou is convertible against $15 \%$ which is ultimate waste. The 2nd, 7th and 13th arrondissements do not have waste collection points. Also, of the 15 regrouping points available to the city, 5 are not functional. The districts that produce more waste in Cotonou are the twelfth which ranks first with 58,408.23 kg followed by the sixth with $44,937.02 \mathrm{~kg}$. The third and thirteenth occupy the third and fourth place with respectively $41,748.73 \mathrm{~kg}$ and $40,851.46 \mathrm{~kg}$.
\end{abstract}

Keywords: Management, solid waste, Cotonou, inventory, outlook.

\section{INTRODUCTION}

\section{Context and rationale for the topic}

The issue of waste management is a major environmental concern, mainly in "developing" countries Jitter (2016). African cities (Lagos, Douala, Abidjan, Lomé, Cotonou, Porto Novo, 
Vol. 6, No. 01; 2021

ISSN: $2456-8643$

etc.) are faced with the problem of waste collection and treatment. Insanitary conditions are remarkable in almost all African cities Akpaki (2009). According to the same author, the legal arsenal put in place is quite impressive but unfortunately suffers from effective enforcement to ensure more efficient waste management. Indeed, Law No. 87-015 of September 21, 1987 on the public hygiene code was for a long time the main legal basis for waste management.

This law prohibits in particular the anarchic dumping of waste of all kinds (refuse, rubbish, wastewater, grease, waste oil, used vehicles, etc.) on public roads as well as their anarchic burial or incineration, fixes the implication of landfills checked at least five kilometers from the last dwellings and at least fifty meters from a water point. This law passed since September 1987 did not have its implementing decree until December 1997, ten (10) years later. Tonon (1987) analyzed the state of sanitation in the city of Cotonou by identifying the various parameters to be taken into account for good waste management.

He emphasized the technical, financial and institutional aspects. According to Tini (2003), for eachactor to be effective, itbecomesnecessary to have a waste management plan thatis global and consistent at the scale of an urbanterritory, in which the sharing of responsibilitiesisclarified. , recognized and accepted by all. The Cotonou town hall isworking on thisthroughitsTechnical Services Department (DST). The latter has the task of providingvarious public services including the management of solidhouseholdwaste (DSM) and devotesitself to it to the best of itsabilities. Despite the efforts made, the situation does not seem to beimproving. Heaps of rubbishlitter the edge of the track, the central openings.

In marshy areas, such as Dandji in the 1st arrondissement, householdwasteisoftenused as backfill and small and medium-sizedenterprises (SMEs) as pre-collection, giventheirmeans of transport (mostlyhuman-drawncarts) encounterdifficulties in accessingit. The samegoes for Agla in the 13th arrondissement. Whatassessmentcanwemake of the management of solidhouseholdwaste in Cotonou afterthreeterms of practice of decentralization in Benin? This studyaims to assess the management system implementedfrom 2001 to 2019 in the city of Cotonou. The workisstructured in two parts. The first part isdevoted to the evaluation of the waste management system in Cotonou from 2001 to 2019. The second part discusses the new reforms introduced in the management of solid household waste through the "Grand Nokoué" project, ie Grand Cotonou.To do this, a methodological approach was used to achieve this objective of the study.

\section{BRIEF PRESENTATION OF THE STUDY ENVIRONMENT}

The city of Cotonou is located in the south of the Republic of Benin between $6^{\circ} 20$ ' and $6^{\circ} 23^{\prime}$ north latitude and $2^{\circ} 22^{\prime}$ 'and $2^{\circ} 30^{\prime}$ east longitude. It is the only municipality in the Littoral department, and is considered the economic capital of the country. It is bounded to the north by Lake Nokoué (Municipality of So-Ava), to the west by the Municipality of Abomey-Calavi, to the east by the Municipality of Sèmè-Kpodji and to the south by the Atlantic Ocean. It covers an area of $79 \mathrm{~km} 2$. The eastern districts are connected to the western part by three bridges. West of Cotonou are the Autonomous Port and Cardinal Bernardin GANTIN International Airport which make the city the most important gateway to and from Benin. On the other hand, in the east, there is an industrial zone, (DEPP / MCOT / 2018) (figure 1). 
Figure 1: Geographical location of the city of Cotonou.

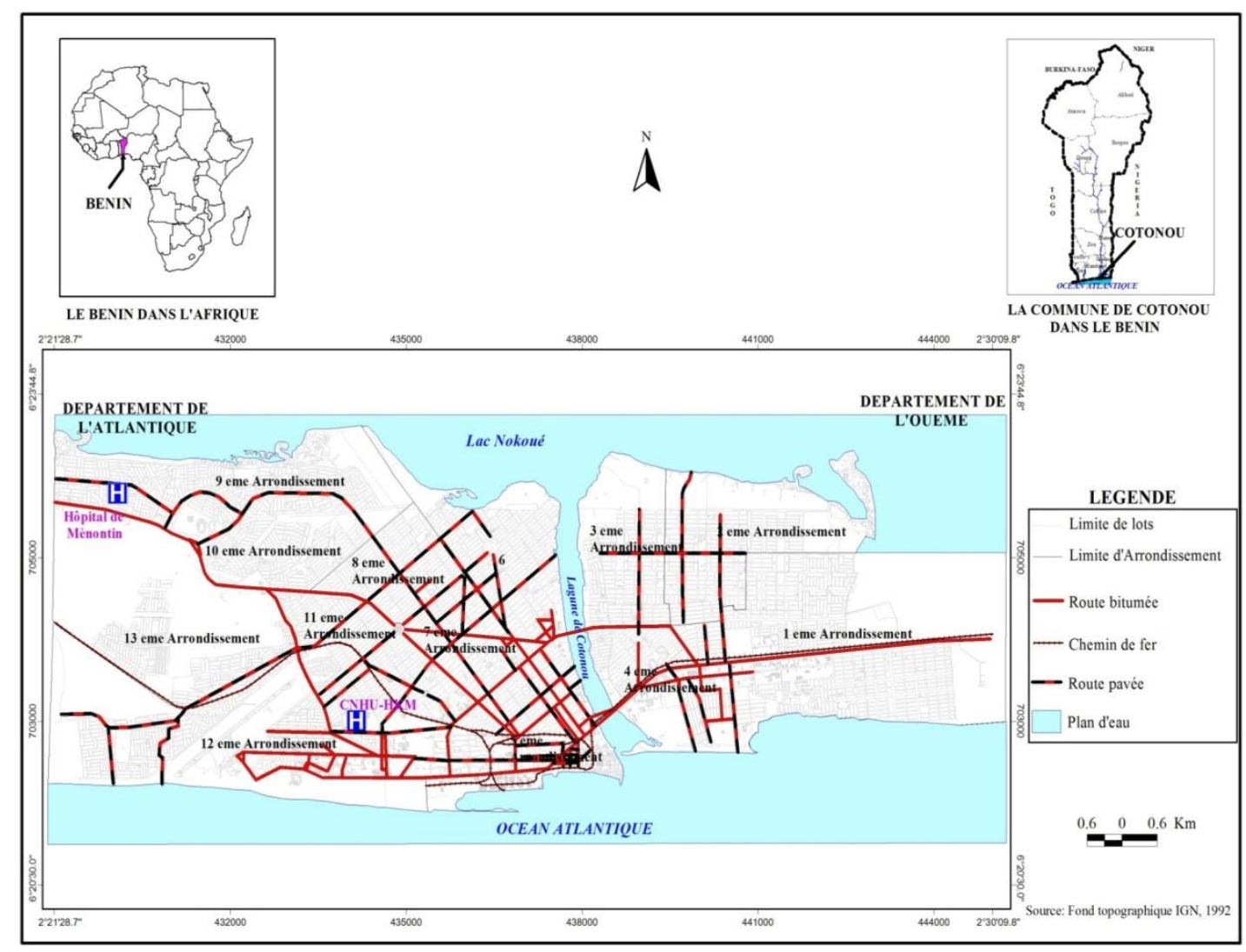

Source: IGN, 1992

Administratively, the city of Cotonou has since the advent of decentralization, 13 districts subdivided into 144 districts. Its population estimated at 320,348 inhabitants in 1979 according to the RGPH1, rose to 536,827 inhabitants in 1992 according to the RGPH2. The population of Cotonou was evaluated at 665,100 inhabitants in 2002 according to the RGPH3, to 679,012 according to the RGPH4, (INSAE 2013). According to the RGPH4, the population of Cotonou was estimated at 679,012 inhabitants against 665,100 inhabitants in 2002, ie an increase rate of $0.18 \%$. Annual intercensal growth rates have trended downward from 1979 to the present $(4.05 \%$ between 1979 and 1992, 2.17\% between 1992 and 2002, and 0.18\% between 2002 and 2013). Any scientific research requires the adoption of a methodological approach for the conduct of the work.

\section{METHODOLOGICAL APPROACH}

The methodological approach used in the context of this research aimed at collecting quantitative and qualitative data. The quantitative data relate to the number of actors involved in waste management (NGOs / SMEs, carters, garbagecollectors, etc.). The qualitative data consists of the assessment of the environmental condition of the city of Cotonou and itsinhabitants. To 
Vol. 6, No. 01; 2021

ISSN: $2456-8643$

obtainthis data and information, various documents on waste in the city of Cotonou we recollected and used. This approach consisted first of doing research on the Internet and other organizations (central libraryat UAC, DGAT) likely to provide information on thistopic. It identified the scientific works, journals and articles necessary for the analysis of solid household waste management and the pre-collection activity.

This approached to the collection of data and information relating to the management of solid household waste in Cotonou and then to the adoption of various methods of their treatment and analysis. The information from the documentary research was supplemented by direct observation in the field. Then the interviews carried out with the waste collection structures and the populations made it possible to better understand the population, its characteristics and the various sanitary problems. In a real environment, research was carried out at the headquarters of a few structures such as the Household Solid Waste Management Project (PGDSM), the Coordination of NGOs for the Management of Household Solid Waste and Sanitation in Cotonou (COGEDA), and in Cotonou Town Hall.

To determine the sample size, use data from the general population and housing census (RGPH 4) of INSAE 2013 and 2019 projection with the formula of Schwarz (1995). Thus, if $n$ denotes the size of the sample, we have: $\mathrm{n}=\mathrm{Z} \alpha 2 \mathrm{x} \mathrm{pq} / \mathrm{i} 2$; with: $\mathrm{Z} \alpha=1.96$, reduced difference corresponding to a risk $\alpha$ of $5 \% ; p=$ proportion or estimation rate of households to be surveyed. This proportion in relation to the number of total households in the commune of Cotonou is the difference between (number of households in the districts surveyed $\mathrm{p}=25 \%$ and total number of households $\mathrm{N}=166,433)$ i.e. $\mathrm{p}=0.25 ; \mathrm{i}=$ desired precision equal at $5 \% ; \mathrm{q}=1-\mathrm{p}$ (here, $\mathrm{q}=$ $0.75) ; \mathrm{N}=(1.96) 2 \times(0.25 \times 0.75) /(0.05) 2=288.12 \approx 288$ The application of this methodology allowed to obtain the following results:

\section{RESULTS OBTAINED}

The presentation of the results goes through the inventory of solid household waste management in Cotonou. First, the management system from 1960 to 2000, then from 2001 to the present day and finally, some suggestions were made for the improvement of the management of solid household waste in the city of Cotonou.

\subsection{State of play of DSM management in Cotonou}

This part is devoted to the presentation of the solid household waste management system in the city of Cotonou from 2001 to 2019. Thus, with regard to previous experiences and taking into account decentralized urban management mechanisms, the option chosen by the authorities municipal organization and management of solid waste is "do-it-yourself" with an obligation of results. This option is based on two basic principles which should guide the solid household waste management policy in Cotonou: participatory management; shared management

\subsubsection{Participatory management}

Management is participatory insofar as, based on the polluter pays principle, households contribute to the financing of the sector by paying a fee for the pre-collection service. The participation of households is made necessary given the current limits of the city of Cotonou in terms of taxation. However, the municipality bears a significant share of the costs by paying for the collection / transport and management of the landfill (LES). The success of solid waste management depends on its acceptance and ownership by all parties involved. To do this, the Cotonou City Council has worked with the stakeholders involved (institutional, private, civil 
Vol. 6, No. 01; 2021

ISSN: $2456-8643$

society) to build its solid household waste management plan.

\subsubsection{Shared management}

One of the conditions for the success of the management plan is the diversification of the operational actors involved and this is possible by segmenting the sector into three stages: precollection, collection / transport and management of the final landfill. Shared management makes it possible to diversify the risk to the extent that when an actor fails, the city is able to intervene at the level of the weak link to impose changes or simply, in the event of a serious failure, replace it. The management plan provides that an operator cannot intervene in two stages of the sector at the same time. Thus, a fairly large number of operational players are involved at each stage of the chain:

Pre-collection is provided by SMEs who pass the waste through collected households to the collection points.

Collection is carried out by the contracting companies whose task is to remove the waste containers at the collection points, to carry out direct collection, all in the direction of the controlled landfill. The landfill is managed by a private manager.

\subsubsection{Institutional option}

The actors of the household solid waste management system (DSM) identified from the surveys respectively for the different phases are listed as follows:

\subsubsection{Actors of the different phases}

Production phase

We mainly distinguish between households, men and women in the streets, public and semipublic establishments, health centers and markets. In this phase, the main actors from the point of view of the quantities of waste produced are households, markets and health centers.

\section{Pre-collection phase}

The stakeholders identified at this level are: the PGDSM, the COGEDA, the pre-collection SMEs, the DST, the residents of the regrouping points, the local elected officials, the environmental police, the health police and the municipal police.

\section{Transport collection phase}

At this stage of the system, there are: The DST, private companies, local elected officials, the MCVDD, the MS, the National Police (MISP), of which private companies and the DST are the main stakeholders.

\section{Treatment phase}

We distinguish the town hall of Cotonou, the MCVDD, the MS, the MISP, however we should not ignore the AGETUR. At this level, the Cotonou town hall and AGETUR are the main players.

\subsubsection{Responsibilities of the different actors}

The town hall of Cotonou is responsible for the implementation of the DSM management system. It coordinates the functionality of the system in accordance with the national sanitation policy.The town hall establishes the sector's operating budget taking into account each segment of the sector.The district chief has a decisive role in ensuring permanent control of the various players in the DSM sector in his territory. He heads the district sanitation committee by organizing weekly consultation meetings with operators (pre-collectors and collector / transporter). The management of the regrouping points is checked weekly. The borough committee defines the performance criteria of the pre-collectors and participates in determining 
the warnings, reprimands and penalties for the pre-collectors who do not meet the performance criteria required of them.Controlling the provision of services by the collector / transporter contributes to the establishment of the penalties and sanctions provided for in his contract.

\subsection{Cotonou Technical Services Department (DST)}

The technical services report directly to the Mayor. The Cotonou Technical Services Department (DST) is involved throughout the entire supply chain (pre-collection, collection / transport and landfill). The DST prepares and presents to the town hall the annual budget of the DSM sector and the tender documents, the control mechanisms of service providers at the level of the various links in the sector as well as statistics relating to the level of performance. of each link in the DSM chain. DST's proposals are subject to the approval of the Mayor.

\subsubsection{Technical organization}

Practical arrangements have been implemented to support the system.

\subsubsection{Zoning}

Zoning is a tool to improve the skills of pre-collection SMEs at the organizational level. It consisted of the spatial distribution of the pre-collectors over the entire territory of Cotonou.

The pre-collection sectors must not overlap in the districts to take into account the administrative division provided for with decentralization.

The implementation of zoning has several objectives, the main ones of which are:

Provide each non-governmental structure (pre-collector) Private enterprise) with its own area / sector of intervention in which its responsibility is engaged;

avoid the atrocious competition between pre-collection SMEs on the one hand and private companies on the other; resolve situations of overlapping activities; provide full coverage of precollection and collection; reduce energy losses by avoiding duplication; master the pre-collection and collection circuit.

Their service is offered for an average monthly subscription fee. The organization of the sector requires some regulation of the fee. To prevent households from being dependent on precollection SMEs, a pricing system has been put in place with the possibility of periodic review. According to information collected in the field, currently the coverage rate of pre-collection by SMEs is around $70 \%$ for the entire city of Cotonou. This rate is variable by sector of intervention and by district. Photo 1 below shows a motorcycle parked at a waste collection site in the 12th arrondissement of Cotonou.

Photo 1:Motorcycle tricycle on a regrouping site in Hindé 


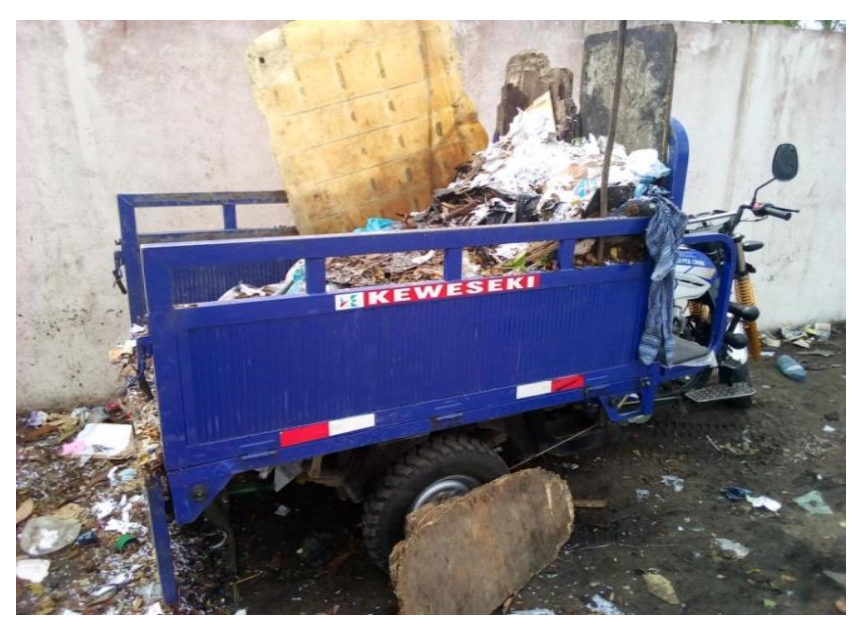

Shooting:Agbani, December 2019 This parkedmotorcycleis the property of an SME responsible for pre-collection at household level. It was bought to allow garbage collectors to be more pragmatic in the field. According to information received from officials of the Technical Services Directorate of the City of Cotonou, an inhabitant of this city produces about $0.5 \mathrm{~kg}$ of waste per day. The amount of waste produced in a day is around $1000 \mathrm{~kg} /$ day, and the town hall, givenitsmeans, can only collect around 500 tonnes. There is therefore on average, 500 tonnes of solidwaste, i.e. 50\% of waste that remains piled up in the city everyday (DST / Mairie de Cotonou, 2019). This assumes that in one year, around 182,500 tonnes of waste remain sun collected.

The subscription rate of the inhabitants of the city of Cotonou is around 68\% to these structures in charge of pre-collection, of which there are 77 (SMEs). Table I below shows the evolution of the population and the production of household solid waste from 2013 to 2019.

Table I: Evolution of the population and production of DSM from 2013 to 2019

\begin{tabular}{|l|l|l|l|l|}
\hline District & $\begin{array}{l}\text { Cotonou population } \\
(2013)\end{array}$ & $\begin{array}{l}\text { Cotonou } \\
\text { population } \\
(2019)\end{array}$ & $\begin{array}{l}\text { Quantity of } \\
\text { QSM produced } \\
\text { in 2019 }(\mathrm{kg})\end{array}$ & $\begin{array}{l}\text { waste produced } \\
\text { per individual / } \\
\text { day / District } \\
(\mathrm{kg})\end{array}$ \\
\hline $1^{\text {er }}$ & 57962 & 58599 & 34573,99 & 0,59 \\
\hline $2^{\text {ème }}$ & 61668 & 62346 & 36784,32 & 0,58 \\
\hline $3^{\text {ème }}$ & 69991 & 70760 & 41748,73 & 0,58 \\
\hline $4^{\text {ème }}$ & 36357 & 36756 & 21686,56 & 0,58 \\
\hline $5^{\text {ème }}$ & 20039 & 20259 & 11953,07 & 0,59 \\
\hline $6^{\text {ème }}$ & 75336 & 76164 & 44937,02 & 0,58 \\
\hline
\end{tabular}


International Journal of Agriculture, Environment and Bioresearch

Vol. 6, No. 01; 2021

ISSN: $2456-8643$

\begin{tabular}{|l|l|l|l|l|}
\hline $7^{\text {ème }}$ & 27535 & 27837 & 16424,41 & 0,59 \\
\hline $8^{\text {ème }}$ & 32420 & 32776 & 19338,21 & 0,59 \\
\hline $9^{\text {ème }}$ & 57691 & 58325 & 34412,22 & 0,59 \\
\hline $10^{\text {ème }}$ & 38728 & 39154 & 23100,87 & 0,59 \\
\hline $11^{\text {ème }}$ & 34879 & 35262 & 20804,99 & 0,59 \\
\hline $12^{\text {ème }}$ & 97920 & 98997 & 58408,23 & 0,58 \\
\hline $13^{\text {ème }}$ & 68486 & 69239 & 40851,46 & 0,58 \\
\hline Total & $\mathbf{6 7 9 0 1 2}$ & $\mathbf{6 8 6 4 7 4}$ & $\mathbf{4 0 5 0 2 4 , 0 8}$ & $\mathbf{7 , 6 1}$ \\
\hline
\end{tabular}

Source: RGPH4 (2013) Projection made by ourselves, February 2020

Observation of this table shows that four arrondissements are the largest producers of solid household waste in the city of Cotonou. The twelfth arrondissement ranks first with 58,408.23 $\mathrm{kg}$. It is followed by the sixth arrondissement with $44,937.02 \mathrm{~kg}$. The third and the thirteenth occupy the third and fourth place respectively. The results of the last general population and housing census clearly indicate that the four arrondissements are the most populous, with 97,920 respectively; 75336; 69,991 and 68,486 inhabitants. It iseasy to see, with some difference, thatthereis a close relationship between the size of the population and the production of solid household waste in the boroughs. The observation is the same with the projection of the Cotonou population which was made from 2013 to 2019. According to the information gathered from the officials of COGEDA, $85 \%$ of the waste produced in Cotonou is convertible against $15 \%$ which is ultimate waste. The Town Hall has implemented a reform which divides the city into 95 regrouping zones and 4 collection and transport zones to the final controlled landfill located in Ouèssè in the commune of Ouidah. These different zones are managed by 77 authorized structures. With regard to waste management, an area has been set up for the treatment of these.The persistence of the problems is due, among other things, to the weak support provided by the central government, to under human and infrastructural equipment of the pre-collection SMEs, to the insufficiency of financial resources for the real-time disposal of solid waste. and household. There is also recurrent incivism, and especially the lack of a policy document for the sustainable management and recovery of garbage in the city or the inadequacy of the content of this to current realities. Despite the difficulties experienced by the City Council in waste management, there is hope in this sector. In fact, five tools developed allow the monitoring and control of the system: the green line, activity reports, dashboards / district committee, reports of proper execution of the pre-collection and the involvement of environmental police, sanitary and municipal DST / MCOT / 2020.

\subsubsection{System weaknesses}

The main weaknesses of the current solid household waste management system in Cotonou relate to both technical and financial aspects.

The second internal problem of SMEs is unilateral management. Indeed, these associative structures which are currently involved in the pre-collection are in reality a real "private company". Because $90 \%$ of them belong to a single individual and not to a group. Quite 
naturally, he recruits people who do the work to whom he pays ridiculous salaries. They come to collect the income from the pre-collection without investing in it properly and without also creating favorable conditions for those who actually do the work. As evidenced by the salary of the carters: $75 \%$ of the carters have a salary between 20,000 and 25,000 and 25\% between 25,000 - 35,000 FCFA francs. This state of affairs leads the carters to behave badly towards households from whom they some times ask for money before removing the garbage. This meagre salary leads them not to also ensure the three regular kidnappings recommended by the contract. In addition, the same carters are developing the phenomenon of clandestine subscriptions and thus contributing to the reduction in the income of their structure. Figure 3 presents the point of view of the people surveyed.

Figure 3: Respondents' point of view

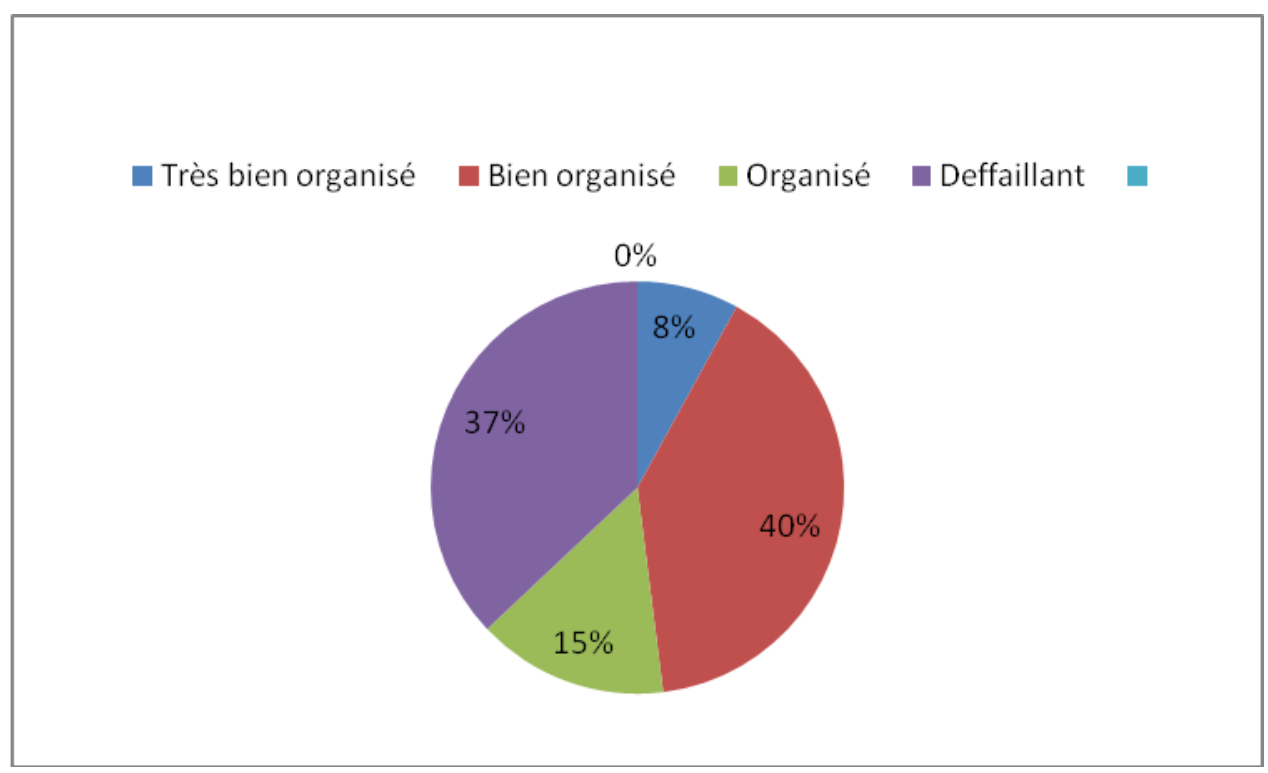

Source: Field survey, December 2019

The analysis in Figure 3 shows that $40 \%$ of respondents find that the system is well organized compared to $37 \%$ who noted a failure of the system in place. Indeed, $15 \%$ of respondents recognize the organization of the system and $8 \%$ find it very well organized.Table III presents the situation of the solid household waste collection points in the city of Cotonou from 2001 to 2019.

Table III: Waste collection points in Cotonou

\begin{tabular}{|l|l|l|l|}
\hline $\mathbf{N}^{\circ}$ & DISTRICTS & GROUPING POINTS & FUNCTIONALITY \\
\hline $\mathbf{1}$ & $1^{\mathrm{er}}$ & Yagbé & $\begin{array}{l}\text { Construction not completed } \\
\text { due to problem of land dispute }\end{array}$ \\
\hline
\end{tabular}


Vol. 6, No. 01; 2021

ISSN: $2456-8643$

\begin{tabular}{|l|l|l|l|}
\hline $\mathbf{2}$ & $2^{\text {ème }}$ & & \\
\hline $\mathbf{3}$ & $3^{\text {ème }}$ & Kpankpan & Functional \\
\hline $\mathbf{4}$ & $4^{\text {ème }}$ & Abokicodji & Functional \\
\hline $\mathbf{5}$ & $5^{\text {ème }}$ & Missèbo & Functional \\
\hline $\mathbf{6}$ & $6^{\text {ème }}$ & Hindé & Functional \\
\hline $\mathbf{7}$ & $7^{\text {ème }}$ & Tonato & \\
\hline $\mathbf{8}$ & $8^{\text {ème }}$ & Mèdédjro & Functional \\
\hline $\mathbf{9}$ & $8^{\text {ème }}$ & Mènontin & No Functional \\
\hline $\mathbf{1 0}$ & $9^{\text {ème }}$ & Fifadji & No Functional \\
\hline $\mathbf{1 1}$ & $10^{\text {ème }}$ & Vodjè & No Functional \\
\hline $\mathbf{1 2}$ & $11^{\text {ème }}$ & Houénoussou & No Functional \\
\hline $\mathbf{1 3}$ & $12^{\text {ème }}$ & AglaHlazounto & Functional \\
\hline $\mathbf{1 4}$ & $12^{\text {ème }}$ & $\begin{array}{l}\text { Centre de Transfert Camp- } \\
\text { Guézo }\end{array}$ & Functional \\
\hline $\mathbf{1 5}$ & $12^{\text {ème }}$ & & \\
\hline $\mathbf{1 6}$ & $13^{\text {ème }}$ & & \\
\hline
\end{tabular}

Source: Results of field surveys / DST December 2019

Analysis of this table shows that the 13 districts of the city of Cotonou do not each have collection points for solid household waste. This is the case for the 2nd, 7th and 13th arrondissements of Cotonou. At the level of the 1st arrondissement, construction is not complete. The regroupment sites of the 8th, 9th, 10th, 11th and 12th arrondissements are not functional because some are confronted with land tenure problems, others with difficulties of access to the sites, still others are confronted with problems of proximity to the houses dwelling.In order to better manage solid household waste in the city of Cotonou, the government has initiated the "Grand Nokoué" project. The project is as follows:

\subsection{Context and objectives of the project}

The conurbation of Grand Nokoué has approximately 2.3 million inhabitants covering the municipalities of Ouidah, Abomey-Calavi, Cotonou, Sèmè-Kpodji and Porto-Novo. This high concentration of people generates an increasing volume of waste, estimated at 385,000 t / year. In constant increase, the quantities of waste produced contribute to increasing the degradation of 
the living environment, including water resources, and more generally the health of populations. This degradation of the urban environment is the result of several factors;poor organization of the sector; the low subscription rate of households to the bodies responsible for collection; the low level of waste removal and its corollary of illegal dumps. More specifically, the aim is to achieve a collection rate of $90 \%$ at 7 years, of which $60 \%$ is recovered waste. The project budget for the 1st year is 10 billion FCFA entirely supported by the government. The purchase of 1,000 light machines for pre-collection of waste and 80 heavy machines for collection. Ouèssè and Takon are the two areas chosen for carrying out the improvement works and operating the sanitary landfill site. The Waste Management and Sanitation Company in Grand Nokoué (Sgds-Gn) has effectively started its activities in the municipalities concerned. Photo 2 shows some of the company's agents at work in the city of Cotonou.

Photo 2: Agents of the company "SGDS-GN"

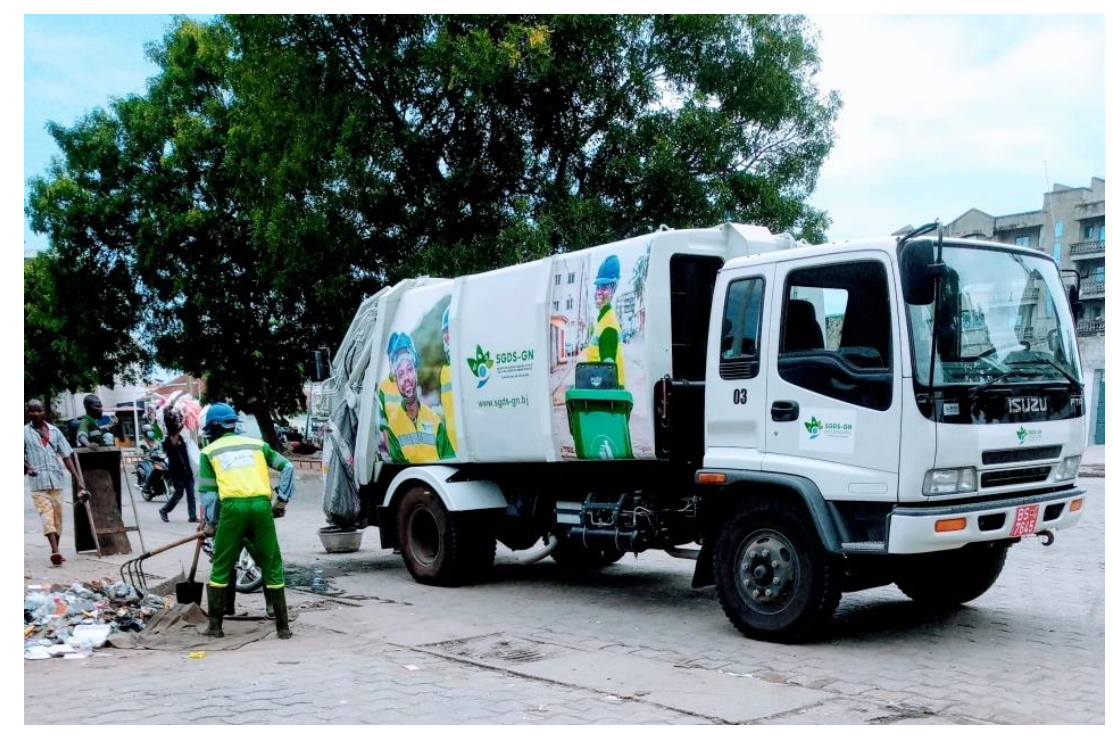

Shooting: Agbani, April 2020 This photo shows the agents of the household solid waste management company in the "Grand Nokoué" atwork in the St Michel district of Cotonou with a household garbage dumpster (BOM) which collects and transports the garbage to the landfill. This garbage truck or garbage truck is specifically designed for the collection and mechanical transport of household garbage and bulky waste. This truck can serve for a long time and becleaned every day without deteriorating. Garbage dumpsters are often equipped with a chopper rotor that fragments and compresses the garbage. It is one of the main modern tools for the collection and collection of rubbish. Work teams are set up and distributed in all the districts of the city of Cotonou, Abomey-Calavi, Ouidah, Sèmè-kpodji and Porto-Novo. All the arteries of the city of Cotonou wereinvadedwiths and and other waste, but after more than 6 months of operation, the observation isthat the sanitation in the city of Cotonou isbetterthan before. The image isnowworthy of Cotonou whichis the showcase of our country Benin as shown in photo 4 . 


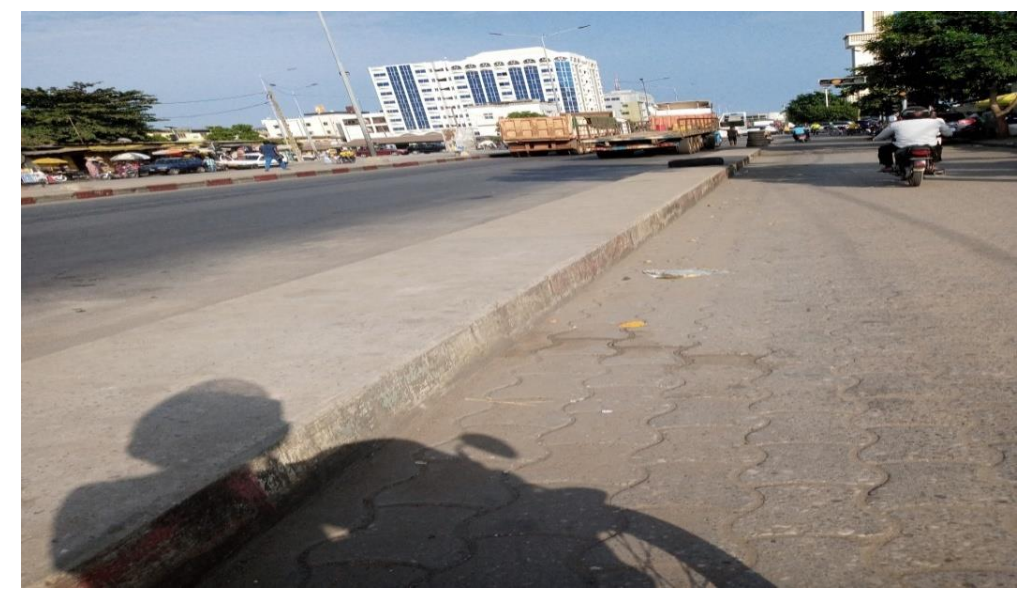

Photo 3: State of cleanliness of the roadway in the Zongo district in Cotonou Shooting:Agbani, April 2020.

This photo shows that the reforms made in the management of solid household waste in the towns of "Grand Nokou" are bearing fruit. In other words, the insalubrity that reigned in Cotonou, especially in the Zongo district, is now associated with the past. This shows that the management of sanitation in the large cities grouped together in Grand Nokoué, is now healthy and optimal with a facilitation of the process of pre-collection, collection and landfill, coupled with a generalization of the collection service. to all households. This project, with a strong social and environmental impact, generates more than 1,500 jobs and is also an opportunity for several small and medium-sized businesses. A territory that generates more than 450,000 tonnes of waste per year. However, the major problems of the old system must betakenintoaccount by the new society. These problems are as follows: - Insufficient collection sites for solid household waste; - Difficulties in accessing certain solid household waste collection sites; - Nonfunctionality of some sites; - Insufficient trucks for the rapidtransfer of containers to sanitarylandfills; - Proximity of some to residentialhouses; - Lack of financial support from the central state.

\section{DISCUSSION}

In the city of Cotonou, we notice that there is a good organization of the solid household waste management sector. The new DSM management plan in the city of Cotonou has a double advantage of being based on a well-defined policy where the responsibilities of each other are defined. The SMEs responsible for the pre-collection have a few shortcomings which mean that the satisfaction of the population of Cotonou is not total. This new plan could help eliminate MSDs from the city if the bottlenecks that persist are corrected and politics are left out. Our results agree with those of the author Blalogoé (2004). Benin, compared to other countries in West Africa has made progress in the field of sanitation in general and in particular for the management of solid household waste in the city of Cotonou.

Our results are similar to studies by Akpaki (2009), according to whom, the large production of waste, its proliferation in public places and the organization of the sector have led to the emergence of solid household waste management activities in the city. fromCotonou. For the same author, waste management activities are organized by NGOs which make sufficient use of the services of carters. But these pre-collection NGOs grouped together within COGEDA are 
Vol. 6, No. 01; 2021

ISSN: $2456-8643$

faced with the problem of subscriber fees. The carters used by these NGOs work in extremely difficult conditions. According to Wari (2012) the elimination of urban waste has long been a question of hygiene and well-being of primary importance in all countries of the world, and even the advantages it can offer in terms of balance and sustainability of cities, as well as public health in particular.

\section{REFERENCES}

AkpakiAdm Joseph (2009): Household solid waste in Cotonou: urban sanitation challenge, article, LEDUR, University of Abomey-Calavi, 2p.

BlalogoéCocou Parfait (2004): New directions for the management of solid household waste in Cotonou, post-graduate diploma in population and urban dynamics, Center for Training and Research in Population, University of Abomey-Calavi, 42 and 52p

DEPP / MCOT (2018): Second generation Communal Development Plan, Cotonou, 36p

DDS / LIT (2019): Statistical Yearbook of the Year 2019, Cotonou, 89 p

DST / MCOT (2019): Study on the conditions of intervention of NGOs for the collection and removal of household waste in certain cities of Benin (Cotonou, Porto-Novo, Ouidah, Lokossa, Savalou, Parakou), 43p.

INSAE 2013: Demographic Survey (EDSB-IV) 2011-2012, Ministry of Development, Economic Analysis and Foresight, ICF International Calverton, Maryland, USA, 36p.

Cotonou Town Hall, (2008): Communal Development Plan, DPDM, 48p

Nathalie Jitter (2016): Dantokpa waste: master's thesis in population and development science, Faculty of Social Sciences, University of Liège, $7 \mathrm{p}$.

UNDP (2006): Synthesis report: study of the impact of land reforms on poverty and the social situation in Benin. UNDP / World Bank / OCS, December 2006, 247p

TiniAppolinaire (2003): The management of solid household waste in Niamey in Niger: essay for a sustainable management strategy, doctoral thesis, INSA de Lyon, 26p

TononFidèle (1987): Contribution to the study of the environment in the People's Republic of Benin: Urban space and solid waste management in the city of Cotonou, Postgraduate thesis in environmental science, Dakar, 309 p.

Wari Saleh Ali, (2012): Problematic of the management of urbanhouseholdwaste in the city of N'djamena: case of the 8th district, Thesis for obtaining the master'sdegree in water and environmental engineering, International Institute for Water and the Environment, 2iE, 21p 